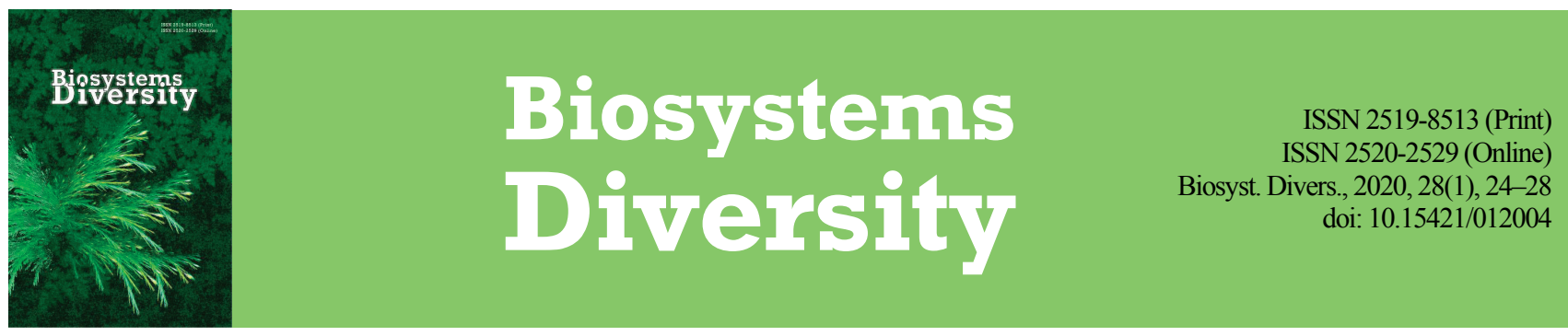

\title{
Distribution, bioecological peculiarities of staphylinids (Coleoptera, Staphylinidae) in livestock biocenoses of forest-steppe and steppe Ukraine
}

\author{
A. P. Paliy*, A. N. Mashkey*, O. I. Kasianenko**, R. V. Petrov**, L. I. Faly***, A. P. Paliï**** \\ *National Scientific Center Institute of Experimental and Clinical Veterinary Medicine, Kharkiv, Ukraine \\ **Sumy National Agrarian University, Sumy, Ukraine \\ ***Oles Honchar Dnipro National University, Dnipro, Ukraine \\ ****Kharkiv Petro Vasylenko National Technical University of Agriculture, Kharkiv, Ukraine
}

Article info

Received 03.01.2020

Received in revised form 11.02.2020

Accepted 15.02.2020

National Scientific Center Institute

of Experimental and Clinical

Veterinary Medicine, Pushkinska st.,

83, Kharkiv, 61023, Ukraine.

Tel.: +38-066-225-34-34.

E-mail:paliy.dok@gmail.com

Sumy National Agrarian University

Gerasim Kondratieva st., 160,

Sumy, 40021, Ukraine.

Tel.: +38-066-392-79-28. E-mail:

romanpetrov1978@gmail.com

Oles Honchar Dnipro National

University, Gagarin Ave., 72,

Dnipro, 49010, Ukraine.

$\mathrm{Tel} \cdot+38-066-600-70-92$

E-mail:faly@ua.fm

Kharkiv Petro Vasylenko National

Technical University of Agriculture,

Alchevskyh st., 44, Kharkiv, 61002,

Ukraine Tel: +38-063-712-82-42

E-mail:paliy.andriy@ukr.net

\section{Introduction}

A relevant task for the agro-industrial complex is the development of efficient biological scientifically-based and rationally-organized methods of control of numerous ectoparasites of agricultural animals. Elimination of invasive diseases significantly increases the volumes of production of livestock products (meat, milk) of high sanitary-hygienic quality (Zazharska et al., 2018; Kulyaba et al., 2019; Gutyj et al., 2019).

Zoophilous dipterans (Insecta, Diptera) ecologically related to the grazing animals include a broad spectrum of forms and species (hematophages, hematophiles, coprophages, representatives of other ecological and ecological-systemic groups) (Jonsson \& Mayer, 1999; Campbell et al., 2001; Baranovski et al., 2016). Diptera have inhabited various habitats. Over the course of evolution, they have adapted to development in small amounts of food substrate (Eggleton \& Belshaw, 1993; Krivosheina, 2008). Activity of zoophilous flies is observed from May to October with peak of abundance in August and September (Lysyk, 1993). The stable fly (Stomoxys calcitrans (Linnaeus, 1758)) is one of the most dangerous species of flies for cattle around the globe (CruzVazquez et al., 2004; Muenworn et al., 2010; Phasuk et al., 2013). Zoophilous dipterans are carriers of many infectious and parasitic diseases (Masmeatathip et al., 2006; Boyko et al., 2009; Saegerman et al., 2018). A whole set of preparations and devices are used against harmful flies. For example, traps of different constructions, distracting food substrates (fruits, flowers) as a source of sugar for adult insects. Chemical agents with various active substances are broadly used for disinfection (Gilles et al., 2007; Müller et al., 2012; Hardy, 2014; Solórzano et al., 2015;
Boyko \& Brygadyrenko, 2017). Negative effects of chemical treatment of livestock complexes stimulates the search of new, more progressive biological methods against ectoparasites (Skovgård \& Nachman, 2004; Ovruski \& Schliserman, 2012; Paliy et al., 2018). The main practical purpose of new methods, at the current stage, is maintaining species diversity of natural enemies of harmful Diptera and their active use in biomethod.

Staphylinidae is the largest family of beetles in the fauna of Ukraine, not taking into account the subfamily Aleocharinae, which is studied insufficiently and subfamilies Pselaphinae and Scaphidiinae, which have been identified to staphylinids relatively recently. In Ukraine 810 species of staphylinids are known, and the total number presumably equals no less than 1,300 species. Species diversity of the family is studied insufficiently, which is indicated by recent descriptions of new species (Gontarenko, 2009, 2013). Genus Philonthus Curtis, 1829 is cosmopolite and numerous by number of species. Global fauna comprises over 1,000 species, including 300 in the Palearctic, in the European part of the CIS the genus is represented by 69 species. The faunistic list of Philonthus genus for the Middle Prydniprovie includes 52 species (Gontarenko \& Petrenko, 2001).

Staphylinids are a significant part of the entomofauna of livestock agrobiocenoses, and are one of the main factors which prevents mass reproduction of dipterans in natural and artificial ecosystems. Species of the Philonthus genus are the dominant group of entomophages which regulates the number of harmful ectoparasites of agricultural animals. An important biological characteristic of entomophages is the indicator of rapid increase in the number of their population. The value of this 
indicator is determined by fertility, rate of the development of generation, ratio of sexes and number of generations per year (Lövei \& Sunderland, 1996; Svobodová et al., 2016). Coprophilous Philonthus undergo a complete life cycle in fecal substrate. Larvae and imagoes of beetles which constantly live in manure eliminate pre-imago stages of synanthropic and zoophilous flies. Concentration of Philonthus in feces of agricultural animals increases in the process of decomposition of excrements (Bruge, 1993; Cabrera \& Chani, 2003). Staphylinids identify their prey by contact, using tactile and taste receptors. They are not able to identify prey at a distance, unlike some species of ground beetles which use eye-sight and smell reflexes. Shape and location of the mandibles in Philonthus (small and average-sized species) determine specialization in piercing relatively large prey, though with soft coverings (Wheater, 1989). The role of staphylinids as bioregulators of the abun-

Table 1

Coordinates of areas of the study and calendar of collecting samples

\begin{tabular}{|c|c|c|c|c|c|}
\hline \multirow{2}{*}{ No } & \multirow{2}{*}{ Territory where samples were collected } & \multicolumn{2}{|c|}{ Date } & \multicolumn{2}{|c|}{ Number of samples } \\
\hline & & year & month & premises & pasture \\
\hline \multirow{4}{*}{1} & \multirow{3}{*}{$\begin{array}{l}\text { Kharkiv Oblast, Zmiiv Raion, Zadonetske village } \\
49.6496^{\circ} \mathrm{N}, 36.3575^{\circ} \mathrm{E} \square\end{array}$} & 2009 & August & - & 15 \\
\hline & & 2012 & July & - & 18 \\
\hline & & 2014 & August & - & 10 \\
\hline & & 2010 & June & - & 20 \\
\hline \multirow{3}{*}{2} & Kharkiv Oblast, Derhachi Raion, Mala Danylivka village & 2012 & August & - & 19 \\
\hline & $50.0766^{\circ} \mathrm{N}, 36.1283^{\circ} \mathrm{E} \square$ & 2014 & June & - & 18 \\
\hline & & 2015 & July & - & 9 \\
\hline \multirow{2}{*}{3} & Kharkiv Oblast, Valky Raion, Ohultsi village & 2005 & May & 8 & 13 \\
\hline & $49.8845^{\circ} \mathrm{N}, 35.8521^{\circ} \mathrm{E} \square$ & 2008 & August & - & 12 \\
\hline \multirow{3}{*}{4} & & 2008 & July & - & 24 \\
\hline & $\begin{array}{l}\text { Kharkiv Ublast, Kharkiv Raion, I emnivka village } \\
497949^{\circ} \mathrm{N} 363384^{\circ} \mathrm{F} \square\end{array}$ & 2013 & July & - & 21 \\
\hline & & 2015 & May & - & 19 \\
\hline \multirow{3}{*}{5} & Kirovohrad Oblast Znamianka Raion Subbotsi village & 2013 & July & 12 & - \\
\hline & $\begin{array}{l}\text { Kirovohrad Oblast, Znamianka Raion, Subbotsi village } \\
486514^{\circ} \mathrm{N} 325005^{\circ} \mathrm{F}\end{array}$ & 2015 & August & 10 & - \\
\hline & & 2015 & November & 18 & - \\
\hline \multirow{2}{*}{6} & Kirovohrad Oblast, Petrove Raion, Luhanka village & 2013 & June & 7 & 18 \\
\hline & $48.1836^{\circ} \mathrm{N}, 33.2857^{\circ} \mathrm{E} \square$ & 2014 & July & 7 & 15 \\
\hline \multirow{2}{*}{7} & Kirovohrad Oblast, Petrove Raion, Petrove village & 2013 & June & 10 & 22 \\
\hline & $48.3339^{\circ} \mathrm{N}, 33.2971^{\circ} \mathrm{E} \square$ & 2014 & July & 5 & 20 \\
\hline 8 & Kherson Oblast, Beryslav Raion, Lvovo village $46.7915^{\circ} \mathrm{N}, 33.1367^{\circ} \mathrm{E} \square$ & 2011 & August & 8 & 15 \\
\hline \multirow{3}{*}{9} & Poltava Oblast Poltaya Raion Kalashnyke villace & 2006 & June & 12 & - \\
\hline & $\begin{array}{l}\text { Poltava Oblast, Poltava Raion, Kalashnyke village } \\
495024^{\circ} \mathrm{N} 34377^{\circ} \mathrm{F}\end{array}$ & 2007 & July & 10 & - \\
\hline & & 2010 & November & 15 & - \\
\hline \multirow{3}{*}{10} & & 2006 & June & 10 & - \\
\hline & Poltava Oblast, Novi Sanzhary Raion, Novi Sanzhary village & 2007 & July & 12 & 18 \\
\hline & $49.3264^{\circ} \mathrm{N}, 34.3339^{\circ} \mathrm{E} \square$ & 2011 & November & 15 & - \\
\hline \multirow{2}{*}{11} & Cherkasy Oblast, Chornobai Raion, Kovrai village & 2005 & June & 15 & - \\
\hline & $49.4684^{\circ} \mathrm{N}, 32.4132^{\circ} \mathrm{E}$ & 2007 & May & 13 & - \\
\hline \multirow{2}{*}{12} & Dnipropetrovsk Oblast, Novomoskovsk Raion, Andriivka village & 2007 & May & - & 25 \\
\hline & $48.7672^{\circ} \mathrm{N}, 35.4531^{\circ} \mathrm{E}$ & 2008 & June & - & 20 \\
\hline
\end{tabular}

In livestock premises the insects were collected manually using aspirators on windows, walls, floor, and also in places of intense breeding of flies (trenches, manure transporters, rotting substrate, manure, separate fecal pats). Density of beetles (number of individuals per $1 \mathrm{~m}^{2}$ of area) was taken into account. For studying the complex of predatory coleopterans on the pastures, fecal pats of cattle of different freshness were surveyed (one to five days). First the pats were examined on the exterior, then the pathways of insects inside them were examined. The soil under the manure substrate was loosened, and the detected insects were extracted, counted and identified. Soil diggings on the pastures were performed according to the existing recommendations (Agrinskiy, 1962; Braga et al., 2013). Some part of the collected material (50\%) was fixated in $70 \%$ ethanol for further survey of species composition of coleopterans, and the remaining part was incubated in the insectarium for further cultivation in laboratory conditions. For mass collection of insects from the litter, manure, we used a thermo-eclector. Laboratory cultivation and experimental study of the peculiarities of the biology of certain species of staphylinids were performed in boxes of the insectarium. Temperature and moisture regimes which directly affect the number of cultivated insects were maintained (Rodríguez et al., 2019). A constant microclimate was maintained in the boxes: temperature of $25-26{ }^{\circ} \mathrm{C}$, relative moisture - to $95 \%$, weak diffused light. Humid river sand was put on the bottom of the boxes. Every day, eggs were extracted from the dance of synantrophic and zoophilous flies in agrobiocenoses of Ukraine has not yet been studied. This determines the relevance and purpose of our studies. The objective of the study was faunistic overview of Staphylinidae in livestock biocenoses of forest-steppe and steppe Ukraine; study of peculiarities of biology and ecology (development, feeding) of dominant coprophilous species of staphylinids in laboratory conditions.

\section{Materials and methods}

Staphylinids were collected from livestock premises, from the territories of farms, manure-depositing sites and pastures located in the forest-steppe and steppe zones of Ukraine (Kharkiv, Poltava, Kirovograd, Cherkassy, Kherson, Dnipropetrovsk Oblasts) in the period from 2005 to 2015 (Table 1). desiccators, and then put into the incubator. Larvae and imagoes of the beetles were fed with different stages of larvae and crushed puparia of laboratory culture of Musca domestica Linnaeus, 1758. Small species of entomophages were kept in Petri dishes on water-moistened filter paper and fed with housefly eggs. Coprophilous species of Philonthus in feces underwent a complete life cycle. Therefore, as substrate for the rearing of Philonthus spinipes Sharp, feces of cattle were used. Beetles were kept in closed boxes (with consideration of high flying activity) with 6 8 individuals in each. Moistened sand and cow manure was put in equal portions on the bottom of the containers.

Assemblages of coleopterans were kept in the collections of the National Scientific Center Institute of Experimental and Clinical Veterinary Medicine of the National Academy of Agrarian Sciences of Ukraine.

\section{Results}

As a result of entomological studies in the territory of livestock complexes, 103 species of predatory coleopterans were found, including $51.4 \%$ Staphylinidae, $27.3 \%$ - Histeridae, $21.3 \%$ - Carabidae. A total of over 2,000 specimens of beetles of the Staphylinidae family was collected and identified. We identified 39 species of staphylinids, belonging to 5 subfamilies: Oxytelinae, Steninae, Tachyporinae, Aleocharinae, Staphylininae (Table. 2). 
Table 2

Species composition of Staphylinidae in livestock biocenoses

\begin{tabular}{|c|c|c|c|}
\hline \multirow[b]{2}{*}{ No } & \multirow[b]{2}{*}{ Species } & \multicolumn{2}{|c|}{ Livestock premises } \\
\hline & & pigpens & $\begin{array}{l}\text { cowsheds / } \\
\text { calf pens }\end{array}$ \\
\hline \multicolumn{4}{|c|}{ Oxytelinae subfamily } \\
\hline 1 & Oxytelus piceus (Linnaeus, 1767) & + & + \\
\hline 2 & O. sculptus Gravenhorst, 1806 & + & + \\
\hline 3 & Anotylus tetracarinatus (Block, 1799) & - & + \\
\hline 4 & A. insecatus (Gravenhorst, 1806) & + & + \\
\hline 5 & Oxytelus sp. & + & - \\
\hline \multicolumn{4}{|c|}{ Steninae subfamily } \\
\hline 6 & $\begin{array}{l}\text { Stenus comma LeConte, } 1863 \\
\text { Tachyporinae subfamily }\end{array}$ & + & + \\
\hline \multicolumn{4}{|c|}{ Aleocharinae subfamily } \\
\hline 8 & Aleochara bilineata Gyllenhaal, 1810 & + & + \\
\hline 9 & A. tristis Gravenhorst, 1806 & - & + \\
\hline 10 & A. intricata Mannerheim, 1830 & + & + \\
\hline 11 & Aleochara bipustulata (Linnaeus, 1761) & - & + \\
\hline 12 & Aleocharasp. & - & + \\
\hline 13 & Aleocharinae gen.sp. & - & + \\
\hline \multicolumn{4}{|c|}{ Staphylininae subfamily } \\
\hline 14 & Leptacinus batychrus (Gyllenhal, 1827) & - & + \\
\hline 15 & Gyrohypnus fracticornis (Müller, 1776) & - & + \\
\hline 16 & Philonthus politus Linnaeus, 1758 & + & + \\
\hline 17 & Ph. addendus Sharp, 1867 & - & + \\
\hline 18 & Ph. succicola Thomson, 1860 & - & + \\
\hline 19 & Ph. rotundicollis Menetries, 1832 & - & + \\
\hline 20 & Ph. rectangulus Sharp, 1874 & - & + \\
\hline 21 & Ph. concinnus Gravenhorst, 1802 & - & + \\
\hline 22 & Ph. longicornis Stephens, 1832 & + & - \\
\hline 23 & Ph. cruentatus (Gmelin, 1790) & + & + \\
\hline 24 & Ph. varians (Paykull, 1789) & + & + \\
\hline 25 & Ph. albipes Gravenhorst, 1802 & - & + \\
\hline 26 & Ph. sordidus (Gravenhorst, 1802) & - & + \\
\hline 27 & Ph. nitidus Fabricius, 1787 & + & + \\
\hline 28 & Ph. quisquiliarius (Gyllenhall, 1810) & + & + \\
\hline 29 & Ph. punctus (Gravenhorst, 1802) & + & + \\
\hline 30 & Ph. fimetarius (Gravenhorst, 1802) & + & - \\
\hline 31 & Ph. spinipes Sharp, 1874 & + & + \\
\hline 32 & Tasgius pedator (Gravenhorst, 1802) & + & + \\
\hline 33 & Ocypus picipennis (Fabricius, 1792) & - & + \\
\hline 34 & O. similis (Fabricius, 1792) & - & + \\
\hline 35 & Staphylinus caesareus Cederhjelm, 1798 & + & - \\
\hline 36 & S. erythropterus Linnaeus, 1758 & + & + \\
\hline 37 & Ontholestes tessellatus (Geoffroy, 1785) & - & + \\
\hline 38 & O. murinus (Linnaeus, 1753) & + & + \\
\hline 39 & Creophilus maxillosus (Linnaeus, 1758) & + & + \\
\hline
\end{tabular}

According to our observations, the most numerous and common species of Staphylinidae on pastures were Anotylus insecatus (Grav.), Oxytelus sculptus Grav., Philonthus nitidus F., Ph. cruentatus (Gmel.), Ph. rectanqulus Sharp, Ph. varians (Payk.), Ph. spinipes Sharp, Ontholestes murinus (L.), Creophilus maxillosus (L.), Aleochara bipustulata (L.), A. bilineata Gyll. The period of maximum activity of staphylinids was May to August. The first species of Staphylinidae were recorded in the surveyed fresh excrements of animals 8-10 $\mathrm{h}$ after the start of the observations. After $24-48 \mathrm{~h}$, the maximum number of beetles was observed. We found Ph. quisquiliarius (Gyll.) occurring more often in fresh $(6-8 \mathrm{~h})$ fecal pats. The high abundance of staphylinids in manure (from 2-day age) is conditioned by mass emergence and development of pre-imago stages of zoophilous flies in it. After the cow pat dries the main mass of Staphylinidae (90\%) migrates in search of fresher fecal mass; and larvae of staphylinids which complete their development there remain in the soil, under remains of manure. It was noted that Ontholestes murinus (L.) and O. tessellatus (Geoff.) can lay eggs in 4 5 day fecal pats of cattle.

Species composition of staphylinids differs in different types of livestock premises (Table 2). In cowsheds and calf pens species diversity was higher -35 species. Density of beetles was on average 5-10 species per $1 \mathrm{~m}^{2}$, and in places of accumulation of manure (large manure heaps) - up to 40 individuals per $1 \mathrm{~m}^{2}$. Dominant species were Oxytelus piceus (L.), O. sculptus Grav., Anotylus insecatus (Grav.), Stenus comma LeCont., Aleochara tristis Grav., Philonthus succicola Thom., Ph. rectangulus Sharp, Ph. varians (Payk), Ph. albipes Grav., Ph. sordidus (Grav.), Creophilus maxillosus (L.). In pigpens 22 species of Staphylinidae were found, average density was $10-15$ specimens per $1 \mathrm{~m}^{2}$, and in places of large accumulation of manure - up to 30 specimens per 1 $\mathrm{m}^{2}$. The number of some species exceeded 100 individuals per $1 \mathrm{~m}^{2}$ (larvae and imagoes of $C$. maxillosus (L.)). Abundant species were Stenus comma LeCont., Ph. politus L., Ph. longicornis Steph., Ph. cruentatus (Gmel.), Ph. varians Payk., Ph. spinipes Sharp, Ph. quisquiliarius (Gyll.), Creophilus maxillosus (L.) Most species of Staphylinidae represented in Table 2 were similarly found in all types of livestock premises. In the cold period of the year manure serves as a safe shelter for staphylinids. In late autumn the beetles concentrate in excrement, and their number can reach $25-30$ individuals in one cow pat $(20-$ $30 \mathrm{~cm}$ in diameter). During 2013-2015, a gradual decrease in the number of predatory coleopterans in pastures of Kharkiv Oblast was observed. Perhaps, this is related to intense exploitation of these lands, transition of most livestock farms to maintenance of cattle in stalls, and also significant decrease in the number of cattle on individual farms. At the same time, in pastures, growth of number of zoophilous and synantrophic flies was recorded. In 2013 fly index (FI) equaled 19-23 specimens, and over 100 in 2015.

On the example of one livestock farm (Kharkiv Oblast, Zmiivsky raion, Zadonetske village), we determined that anti-parasitic preparations (Albendazole) which were introduced into the organisms of cattle (April of 2009-2012) have no effect on the development of pre-imago phases of flies in dung, and therefore, on the number and species composition of staphylinids.

For the study of food specialization in the laboratory conditions, 9 species of coprophilous staphylinids were monitored. Adult beetles of Philonthus addendus Sharp collected in cowsheds were fed with house fly larvae of II and III age. We determined that over $24 \mathrm{~h}$ one imago ate 2-3 larvae of flies. Larvae of beetles at I age (with partial eating-out of the internal organs) over $24 \mathrm{~h}$ consumed 2-4 I age larvae of flies. Beetle larvae in III age - 5-8 II-III age larvae of flies. Over cultivation we obtained 4 generations of $P h$. addendus Sharp. Larvae of Ph. cruentatus (Gmel.) were fed with crushed pupae of M. domestica L. Over $24 \mathrm{~h}$ one adult beetle consumed 2-3 puparia of flies. The species was cultivated to 4th generation. Coprobiontic Ph. rectangulus Sharp caught on pastures were kept in the culture to 4 th generation. Over $24 \mathrm{~h}$ imagoes consumed 2-3 I age larvae of flies and crushed puparia. During observations on feeding of $P h$. varians (Payk.) we noted elements of necrophagia. The beetles ate remains of the larvae and puparia of flies, which had been torn by other large species of staphylinids. During $24 \mathrm{~h}$ one beetle consumed 3-5 housefly eggs. The species was cultivated to $3 \mathrm{rd}$ generation. In the experiment $P h$. spinipes Sharp imagoes preferred to feed on larvae of flies of the final age (4-5 larvae a day). One of the most abundant species in our assemblages was Ph. nitidus F. It is common in the territory of swine and cattle farms of the forest-steppe zone of Ukraine. In the culture it was kept to the 6th generation. Over $24 \mathrm{~h}$, the beetles consumed 3-4 adult houseflies and 3-6 larvae of older age. Imagoes can also feed on puparia of flies, gnawing holes inside them and eating the soft tissues. Larvae of Ph. nitidus of I age actively attacked I-II age larvae of flies (5-6 specimens a day), and less eagerly consumed III age larvae. As prey, II age larvae chose II-III age larvae of M. domestica L. and ate 5-6 individuals a day. Third age larvae of $P h$. nitidus $\mathrm{F}$., apart from consuming larvae of flies of older ages, attacked the pupae. Over $24 \mathrm{~h}$ they consumed 5-7 larvae of flies and 2-4 pupae. Beetles of Creophilus maxillosus (L.) collected under the litter of pigpens were fed with III age larvae, puparia and imagoes of housefly. During the experiment, over 5 days one adult individual consumed $55 \mathrm{III}$ age larvae and 10 puparia of $M$. domestica $\mathrm{L}$. During the cultivation, 3 generations of C. maxillosus (L.) were obtained. Ontholestes murinus (L.) was cultivated to 4 th generation. Over $24 \mathrm{~h}$ imagoes of this species ate up to $10 \mathrm{III}$ age larvae of flies. Adult Oxytelus sp. were collected in feces of cattle in pastures. The beetles feed on rotting substrate, therefore as fodder crushed pupae of M. domestica L. were used. Two generations were obtained.

Peculiarities of the development of coprophilous staphylinids were studied on the example of the abundant species $P h$. spinipes Sharp. This cosmopolitan species is new to the fauna of Ukraine. The beetles are closely associated with manure (pre-imago development) in cattle pas- 
tures. Imagoes occur in the pathways of coprophages until late autumn. According to our observations, this species was not recorded in other substrates (forest litter, corpses of animals, etc). In the culture it was kept to 3 rd generation. In natural conditions, females of coprophilous Philonthus lay eggs in the layer of fecal substrate. In the laboratory egg-laying of Philonthus was observed in the lower and middle layers of manure (with thickness of the substrate in the container equaling $3 \mathrm{~cm}$ ). Eggs were located singly or in accumulations of $4-5$ specimens. Over $24 \mathrm{~h}$ one female laid $1-3$ eggs (in $+28^{\circ} \mathrm{C}$ ). During observations on separately placed pairs of $P h$. spinipes Sharp imagoes, freshly laid eggs were observed every day. The duration of the egg phase depends on the temperature regime $\left(4-5\right.$ in $+20^{\circ} \mathrm{C}$, and $3-4$ in $\left.+28^{\circ} \mathrm{C}\right)$. On average one female $P h$. spinipes Sharp laid 40 eggs. Egg-laying ceased when the temperature dropped to $+14^{\circ} \mathrm{C}$. Duration of the larva phase was also conditioned by temperature conditions: $8-10$ days in $+28^{\circ} \mathrm{C}, 13-14$ in $+20^{\circ} \mathrm{C}$. The larva develops in three stages. The first moulting was observed on the $2-3 \mathrm{rd}$ days $\left(\mathrm{in}+28^{\circ} \mathrm{C}\right.$ ) after larvae hatched from the eggs. The upper layers of manure rapidly lose moisture, therefore Philonthus transform into pupae in middle and lower layers of the substrate. Lastage larvae of $P h$. spinipes Sharp constructs an air chamber with smooth walls in the excrements a few days before pupation. The larva transforms into pupa in 20-40 seconds. The cuticle is torn in the direction from head to the segments of the abdomen. With wave-like movements the pupa frees itself from the larva coatings and turns to the ventral side. It remains motionless in this position. At $+28^{\circ} \mathrm{C}$ the pupa phase lasts 8 10 days. Decrease in the temperature prolongs the development. At +24 ${ }^{\circ} \mathrm{C}$ it practically did not change (9-10 days), at $+18^{\circ} \mathrm{C}$ it was prolonged to $13-15$ days. During this phase the pupa was observed to undergo change in colour from yellow to dark-brown.

\section{Discussion}

Prolonged anthropogenic activity influences the dynamics and structure of Staphylinidae communities. It has been proved that technogenic pollution causes changes in the linear sizes and morphometric features of staphylinids (Faly, 2010). The number and biomass of short-elytra beetles does not change significantly, species diversity decreases and changes in the composition of the dominants occurs. This group of coleopterans can be an indicator of anthropogenic changes in the environment (Edwards, 1991; Bogach, 1993). A relevant task is maintaining species diversity of Staphylinidae as a potential natural enemy of harmful dipterans.

According to our observations, over recent years the number of coleopterans in the pastures has been seen to decrease. Perhaps, this is related to transition of most livestock farms to maintenance of animals in stalls as well as decrease in the number of livestock on individual farms. For preventing significant losses of production of livestock, caused by attacks of parasitic insects, two technogenic approaches exist in livestock farming. The first approach is based on no-pasture maintenance of cattle along with traditional grazing in summer. The second approach is based on protective treatments of animals using insecticidal and repellent preparations (von Stein \& Soderlund, 2012). Rapid decrease in the number of predatory beetles (from 40 to 5-8 individuals per $1 \mathrm{~m}^{2}$ ) is observed not only in pastures, but also in livestock premises, which in our opinion is related to uncontrolled use of chemical preparations against flies. An important role in the development of larvae of zoophilous flies in the places of feeding the animals belongs to hay. Manure mixed with hay is known to contribute to more stable and rapid development of flies (Talley et al., 2009). Timely cleaning of the fodder remains and systematic selection of samples in livestock premises allow reduction and prediction of the number of harmful dipterans (Skoda et al., 1991).

On livestock farms, regardless of the form of ownership, a number of measures are taken for protecting animals against infectious and invasive diseases. Among these measures an important role belongs to protection against zoophilous flies. Despite its disadvantages, the biomethod still remains a poorly developed scientific sphere, which is explained by the difficulties in controlling the relations between useful and harmful organisms in the environment. Mass use of toxic environmentpolluting insecticides in livestock causes the necessity to developf ecologically safe methods against dipterans. These methods should be based on modern knowledge of the peculiarities of zoophilous flies and their entomophages.

\section{Conclusions}

In livestock complexes of Kharkiv, Poltava, Kirovohrad, Cherkassy, Kherson and Dnipropetrovsk Oblasts of Ukraine, 103 species of predatory Coleoptera were found: Staphylinidae equaled $51.4 \%$, Histeridae $-27.3 \%$, Carabidae $-21.3 \%$ of the total. During the period of 2013-2015 in the studied territories the number of coleopterans was observed to decrease. Perhaps, this is related to increased exploitation of the land, transition of most farms to stall maintenance of animals and decrease in the number of cattle.

We identified the species composition and dominant species of staphylinids - potential bioregulators of the number of zoophilous flies in the territory of livestock complexes. Total of 39 species was found, belonging to 5 subfamilies: Oxytelinae, Steninae, Tachyporinae, Aleocharinae, Staphylininae. The dominant species of staphylinids in the pastures were Anotylus insecatus (Grav.), Oxytelus sculptus Grav., Philonthus nitidus F., Ph. cruentatus (Gmel.), Ph. rectanqulus Sharp, Ph. varians (Payk.), Ph. spinipes Sharp, Ontholestes murinus (L.), Creophilus maxillosus (L.), Aleochara bipustulata (L.), A. bilineata Gyll. Species diversity of staphylinids was higher in cowsheds and calf pens.

In laboratory conditions, the peculiarities of feeding of larvae and imagoes of 9 species of Staphylinidae were studied: Philonthus addendus Sharp, Ph. cruentatus (Gmel.), Ph. rectangulus Sharp, Ph. varians (Payk.), Ph. spinipes Sharp, Ph. nitidus F., Creophilus maxillosus (L.), Ontholestes murinus (L.), Oxytelus sp. We determined high feeding activity of beetles: mass of consumed food per day exceeded the weight of the insect. Over the period of their development, staphylinids on average consume and traumatize 70-100 larvae of flies of different ages. We observed a pattern in the relationship between the sizes of predator and victim. Large species of staphylinids attack fly larvae of the last age and are able to eat puparia.

We determined that over $24 \mathrm{~h}$ one female $P h$. spinipes Sharp lays 1-3 eggs (in $+28^{\circ} \mathrm{C}$ ). Duration of the egg phase at $+20^{\circ} \mathrm{C}$ was $4-5$, at $+28^{\circ} \mathrm{C}-3-4$ days. Egg-laying was observed to stop at $+14^{\circ} \mathrm{C}$. Development occurs in three larval stages. Duration of the larva phase in $+28^{\circ} \mathrm{C}$ was 8-10 days, and at $+20^{\circ} \mathrm{C}-13-14$ days. The first moult was observed on the $2-3$ rd days $\left(\right.$ in $+28^{\circ} \mathrm{C}$ ) after the larva emerged from the egg. Pupa phase in $+28^{\circ} \mathrm{C}$ lasted 8-10 days. Decrease in temperature prolonged the development. At $+24{ }^{\circ} \mathrm{C}$ it practically did not change (9-10 days), at $+18^{\circ} \mathrm{C}$ it increased to $13-15$ days.

On the basis of study of bioecological peculiarities of coprophilous staphylinids, promising species can be distinguished - entomophages for use in bioregulation of the number of zoophilous flies. The obtained data form a practical basis for developing ecologically clean biological methods against parasitic dipterans in livestock rearing premises.

\section{References}

Agrinskiy, N. I. (1962). Nasekomyye i kleshchi, vredyashchiye sel'skokhozyaystvennym zhivotnym [Insects and ticks harmful to farm animals]. Moscow (in Russian).

Baranovski, B., Khromykh, N., Karmyzova, L., Ivanko, I., \& Lykholat, Y. (2016). Analysis of the alien flora of Dnipropetrovsk province. Biological Bulletin of Bogdan Chmelnitskiy Melitopol State Pedagogical University, 6(3), 419-429.

Bogach, Y. A. (1993). Zhuki-stafilinidy (Coleoptera, Staphylinidae) kak bioindikatory ekologicheskogo ravnovesiya $\mathrm{v}$ landshafte i vliyaniya cheloveka na primere goroda Pragi [Staphylinid beetles (Coleoptera, Staphylinidae) as bioindicators of ecological balance in the landscape and human influence on the example of the city of Prague]. Bioindication in cities and suburban areas. Moscow. Pp. 36- 42 (in Russian).

Boyko, A., Brygadyrenko, V., Shendryk, L., \& Loza, I. (2009). Estimation of the role of antropo-zoonosis invasion agents in the counteraction to bioterrorism. Counteraction to Chemical and Biological Terrorism in East European Countries. NATO Science for Peace and Security Series A: Chemistry and Biology. Springer Nature, 309-315.

Boyko, A. A., \& Brygadyrenko, V. V. (2017). Changes in the viability of Strongyloides ransomi larvae (Nematoda, Rhabditida) under the influence of synthetic flavourings. Regulatory Mechanisms in Biosystems, 8(1), 36-40.

Braga, R. F., Korasaki, V., Andresen, E., \& Louzada, J. (2013). Dung beetle community and functions along a habitat-disturbance gradient in the Amazon: 
A rapid assessment of ecological functions associated to biodiversity. PLoS One, 8(2), e57786.

Bruge, H. (1993). Philonthus (Kenonthus) spinipes Sharp Belg. sp. n. (Coleoptera Staphylinidae, Staphylininae). Bulletin et Annales de la Societe Royale Belge D'entomologie, 129, 29-30.

Cabrera, W. G., \& Chani, P. M. (2003). Abundance and seasonal distribution of predatory coprophilous argentine rove beetles (Coleoptera: Staphylinidae), and their effects on dung breeding flies. The Coleopterists Bulletin, 57(1), 43-50.

Campbell, J. B., Skoda, S. R., Berkebile, D. R., Boxler, D. J., Thomas, G. D., Adams, D. C., \& Davis, R. (2001). Effects of stable flies (Diptera: Muscidae) on weight gains of grazing yearling cattle. Journal of Economic Entomology, 94(3), 780-783.

Cruz-Vazquez, C., Mendoza, I. V., Parra, M. R., \& Garca-Vazquez, Z. (2004). Influence of temperature, humidity and rainfall on field population trend of Stomoxys calcitrans (Diptera: Muscidae) in a semiarid climate in Mexico. Parasitologia Latinoamericana, 59(3-4), 99-103.

Edwards, C. A. (1991). The assessment of population of soil-inhabiting invertebrates. Agriculture, Ecosystems and Environment, 34(1-4), 145-176.

Eggleton, P., \& Belshaw, R. (1993). Comparisons of dipteran, hymenopteran and coleopteran parasitoids: Provisional phylogenetic explanations. Biological Journal of the Linnean Society, 48(3), 213-226.

Faly, L. I. (2010) Vliyaniye tekhnogennogo zagryazneniya na izmeneniye morfometricheskikh priznakov u Philonthus spinipes (Coleoptera, Staphylinidae) [The effect of technogenic pollution on the change in morphometric characters in Philonthus spinipes (Coleoptera, Staphylinidae)]. Materials of the III International Scientific and Practical Internet Conference "Actual Issues of Entomology". Stavropol. Pp. 19-21 (in Russian)

Gilles, J., David, J. F., Duvallet, G., De La Rocque, S., \& Tillard, E. (2007). Efficiency of traps for Stomoxys calcitrans and Stomoxys niger niger on Reunion Island. Medical and Veterinary Entomology, 21(1), 65-69.

Goncharov, N. R., \& Belyakov, N. A. (2011). Innovatsionnyy proyekt po masshtabirovaniyu proizvodstva biologicheskikh sredstv zashchity rasteniy [Innovative project for scaling the production of biological plant protection means]. IDBF Newsletter, 42, 57-60 (in Russian).

Gontarenko, A. V. (2009). Adventivnyye vidy stafilinid (Coleoptera: Staphylinidae) fauny Ukrainy [Adventive staphylinids (Coleoptera: Staphylinidae) of the fauna of Ukraine]. The Kharkov Entomological Society, 17(1-2), 15-19. (in Russian).

Gontarenko, A. V. (2013). Interesnyye nakhodki zhukov-stafilinid (Coleoptera: Staphylinidae) iz Ukrainy [Interesting finding of rove beetles (Coleoptera: Staphylinidae) from Ukraine]. The Kharkov Entomological Society, 21(2), 5-8 (in Russian).

Gontarenko, A. V., \& Petrenko A. A. (2001). Novyye dlya fauny Ukrainy i Moldovy vidy roda Philonthus Curt. (Coleoptera, Staphylinidae, Staphylininae) [Species of the genus Philonthus Curt., new to the fauna of Ukraine and Moldova (Coleoptera, Staphylinidae, Staphylininae)]. Scientific Works of the Zoological Museum of Odessa National University, 4, 63-64 (in Russian).

Gutyj, B. V., Ostapyuk, A. Y., Sobolev, O. I., Vishchur, V. J., Gubash, O. P., Kurtyak, B. M, Kovalskyi, Y. V., Darmohray, L. M., Hunchak, A. V., Tsisaryk, O. Y., Shcherbatyy, A. R., Farionik, T. V., Savchuk, L. B., Palyadichuk, O. R., \& Hrymak, K. (2019). Cadmium burden impact on morphological and biochemical blood indicators of poultry. Ukrainian Journal of Ecology, 9(1), 236-239.

Hardy, M. C. (2014). Resistance is not futile: It shapes insecticide discovery. Insects, 5(1), 227-242.

Jonsson, N. N., \& Mayer, D. G. (1999). Estimation of the effects of buffalo fly (Haematobia irritans exigua) on the milk production of dairy cattle based on a metaanalysis of literature data. Medical and Veterinary Entomology, 13(4), 372-376

Krivosheina, M. G. (2008). Biology of xylobiont larvae of limoniid flies of the genus Gnophomyia (Diptera, Limoniidae) with description of immature stages. Entomological Review, 88(7), 793-807.

Kulyaba, O., Stybel, V., Gutyj, B., Turko, I., Peleno, R., Turko, Y., Golovach, P., Vishchur, V., Prijma, O., Mazur, I., Dutka, V., Todoriuk, V., Golub, O., Dmytriv, O., \& Oseredchuk, R. (2019). Effect of experimental fascioliasis on the protein synthesis function of cow liver. Ukrainian Journal of Ecology, 9(4), 612-615

Lövei, G. L., \& Sunderland, K. D. (1996). Ecology and behavior of ground beetles (Coleoptera: Carabidae). Annual Review of Entomology, 41, 231-256.

Lysyk, T. J. (1993). Seasonal abundance of stable flies and house flies (Diptera: Muscidae) in dairies in Alberta, Canada. Journal of Medical Entomology, 30(5), 888-895.

Masmeatathip, R., Gilles, J., Ketavan, C., \& Duvallet, G. (2006). First survey of seasonal abundance and daily activity of Stomoxys spp. (Diptera: Muscidae) in Kamphaengsaen Campus, Nakompathom province, Thailand. Parasite, 13(3), 245-250.

Muenworn, V., Duvallet, G., Thainchum, K., Tuntakom, S., Tanasilchayakul, S., Prabaripai, A., Akratanakul, P., Sukonthabhirom, S., \& Chareonviriyaphap, T. (2010). Geographic distribution of stomoxyine flies (Diptera: Muscidae) and diurnal activity of Stomoxys calcitrans in Thailand. Journal of Medical Entomology, 47(5), 791-797.

Müller, G. C., Hogsette, J. A., Beier, J. C., Traore, S. F., Toure, M. B., Traore, M. M., Bah, S., Doumbia, S., \& Schlein, Y. (2012). Attraction of Stomoxys sp. to various fruits and flowers in Mali. Medical and Veterinary Entomology, 26(2), 178-187.

Ovruski, S. M., \& Schliserman, P. (2012). Biological control of tephritid fruit flies in Argentina: Historical review, current status, and future trends for developing a parasitoid mass-release program. Insects, 3(3), 870-888.

Paliy, A. P., Sumakova, N. V., Paliy, A. P., \& Ishchenko, K. V. (2018). Biological control of house fly. Ukrainian Journal of Ecology, 8(2), 230-234.

Phasuk, J., Prabaripai, A., \& Chareonviriyaphap, T. (2013). Seasonality and daily flight activity of stable flies (Diptera: Muscidae) on dairy farms in Saraburi Province, Thailand. Parasite, 20, 17

Rodríguez W. D., Klimaszewski, J., Navarrete-Heredia, J. L \& Guevara, R (2019). The influence of environmental temperature and humidity on the elevational and temporal distributions of rove beetles (Coleoptera: Staphylinidae) in a Quercus L. forest in Jalisco, Mexico. The Coleopterists Bulletin, 73(1), 202-224.

Saegerman, C., Bertagnoli, S., Meyer, G., Ganière, J.-P., Caufour, P., De Clercq, K., Jacquiet, P., Fournié, G., Hautefeuille, C., Etore, F., \& Casal, J. (2018). Risk of introduction of lumpy skin disease in France by the import of vectors in animal trucks. PLoS One, 13(6), e0198506.

Skoda, S. R., Thomas, G. D., \& Campbell, J. B. (1991). Developmental sites and relative abundance of immature stages of the stable fly (Diptera: Muscidae) in beef cattle feedlot pens in Eastern Nebraska. Journal of Economic Entomology, 84(1), 191-197.

Skovgård, H., \& Nachman, G. (2004). Biological control of house flies Musca domestica and stable flies Stomoxys calcitrans (Diptera: Muscidae) by means of inundative releases of Spalangia cameroni (Hymenoptera: Pteromalidae). Bulletin of Entomological Research, 94(6), 555-567.

Solórzano, J. A., Gilles, J., Bravo, O., Vargas, C., Gomez-Bonilla, Y., Bingham, G. V., \& Taylor, D. B. (2015). Biology and trapping of stable flies (Diptera: Muscidae) developing in pineapple residues (Ananas comosus) in Costa Rica. Journal of Insect Science, 15, 145.

Svobodová, Z., Skoková Habuštová, O., Boháč, J., \& Sehnal, F. (2016). Functional diversity of staphylinid beetles (Coleoptera: Staphylinidae) in maize fields: Testing the possible effect of genetically modified, insect resistant maize. Bulletin of Entomological Research, 106(4), 432-445.

Talley, J., Broce, A., \& Zurek, L. (2009). Characterization of stable fly (Diptera: Muscidae) larval developmental habitat at round hay bale feeding sites. Journal of Medical Entomology, 46(6), 1310-1319.

von Stein, R. T., \& Soderlund, D. M. (2012). Role of the local anesthetic receptor in the state-dependent inhibition of voltage-gated sodium channels by the insecticide metaflumizone. Molecular Pharmacology, 81(3), 366-374

Wheater, C. P. (1989). Prey detection by some predatory Coleoptera (Carabidae and Staphylinidae). Journal of Zoology, 218(2), 171-185.

Zazharska, N., Boyko, O., \& Brygadyrenko, V. (2018). Influence of diet on the productivity and characteristics of goat milk. Indian Journal of Animal Research, 52(5), 711-717. 